\title{
Variable respiration rates of incubated permafrost soil extracts from the Kolyma River lowlands, north-east Siberia
}

\author{
Joanne K. Heslopa, Sudeep Chandraa, William V. Sobzcak', Sergey P. Davydov', Anna I. Davydovac, \\ Valentin V. Spektor ${ }^{\mathrm{d}}$ \& Katey M. Walter Anthony ${ }^{\mathrm{e}}$
}

aquatic Ecosystems Analysis Laboratory, Department of Natural Resources and Environmental Science, University of Nevada, Reno, NV, USA; ${ }^{b}$ Department of Biology, College of the Holy Cross, Worcester, MA, USA; 'North-East Science Station, Pacific Institute of

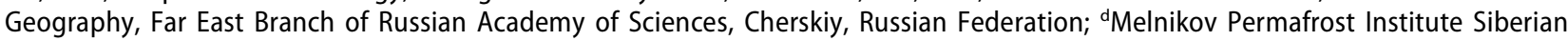
Branch, Russian Academy of Sciences, Republic of Sakha (Yakutia), Yakutsk, Russian Federation; eWater and Environmental Research Center, University of Alaska Fairbanks, Fairbanks, AK, USA

\begin{abstract}
Thawing permafrost supplies dissolved organic carbon (DOC) to aquatic systems; however, the magnitude, variability and fate of this DOC is not well constrained. Our objective was to examine DOC respiration from seasonally thawed and near-surface $(<1.5 \mathrm{~m})$ permafrost soils collected from five locations in the Kolyma River Basin, north-east Russia. We measured soil organic carbon $(\mathrm{OC})$ content, water-soluble macronutrients $\left(\mathrm{DOC}, \mathrm{NH}_{4}, \mathrm{PO}_{4}\right)$ and the heterotrophic respiration potentials of soil extract DOC in five-day laboratory incubations. DOC concentrations ranged from 2.8 to $27.9 \mathrm{mg} \mathrm{L}^{-1}(n=14)$. Carbon respiration was $0.03-0.47 \mathrm{mg}$ C $(n=16)$ and $8.7-31.4 \%$, total DOC $(n=14)$. While DOC concentration was a function of soil OC concentration, we did not find a relationship between $C$ respiration and soil OC or DOC concentrations. Respiration was highest in the top active layer, but varied widely among sites, and lowest at the bottom of the active layer. Respiration from yedoma varied across sites (0.04-0.47 mg C respired, 8.7-31.4\% total DOC). Despite the small sample size, our study indicates near-surface soils and permafrost are spatially variable in terms of both soil OC content and $C$ respiration rates, and also that $O C$ contents do not predict $C$ respiration rates. While a larger sample size would be useful to confirm these results at broader geographic scales, these initial results suggest that soil OC heterogeneity should be considered in efforts to determine the fate of soil OC released from permafrost-dominated terrestrial ecosystems to aquatic ecosystems following permafrost thaw.
\end{abstract}

\section{KEYWORDS}

Arctic; carbon export and processing; yedoma; climate change; greenhouse gas production

\section{ABBREVIATIONS}

BOD: biological oxygen demand; DOC: dissolved organic carbon; OC: organic carbon; SE: standard error; $\mathrm{NH}_{4}-\mathrm{N}$ : ammonium; $\mathrm{PO}_{4}-\mathrm{P}$. orthophosphate
Perennially frozen ground (permafrost) contains a vulnerable $\mathrm{C}$ pool susceptible to warming and thaw (Zimov, Schuur et al. 2006; Schuur et al. 2008; Schuur et al. 2015). Permafrost covers $22 \%$ of the Northern Hemisphere (Brown et al. 1998) and contains an estimated 1140-1580 Pg of OC - approximately half of the world's belowground OC (Hugelius et al. 2014; Schuur et al. 2015). Temperatures in the Arctic have increased an average of $0.6^{\circ} \mathrm{C}$ per decade over the last 30 years, which is twice as fast as the global average (Stocker et al. 2013). This climate warming triggers the release of permafrost $\mathrm{OC}$ via permafrost thaw and erosion, exporting large amounts of terrestrial $\mathrm{C}$ to aquatic environments (Striegl et al. 2005; Frey \& McClelland 2009; Vonk et al. 2013; Cory et al. 2014; Larouche et al. 2015) and making previously frozen OC from a range of soil depths available for microbial decomposition (Goulden et al. 1998; Dutta et al. 2006; Schuur et al. 2008; Tarnocai et al. 2009; Vonk et al. 2013; Mann et al. 2014). Thaw depths of the seasonally thawed active layer rapidly respond to warming air temperatures (Hinkel \& Nelson 2003; Frauenfeld et al. 2004) and active layer thicknesses are projected to increase as a result of climate warming, releasing fractions of previously frozen OC from near-surface permafrost (Zhang et al. 2005; Frey \& McClelland 2009).

Deepening active layers are projected to increase the degree of interaction between soils and water (Neff et al. 2006; Battin et al. 2008; Davydov et al. 2008; Frey \& McClelland 2009), allowing water-soluble fractions of recently thawed OC to dissolve into soil water. The permafrost underlying the active layer prevents the subsurface flow from percolating deeper (Wickland et al. 2007), facilitating soil water export which, in turn, may lead to an increase in the export of permafrost OC to inland waters (Vonk et al. 2013; Spencer et al. 2015). Dissolved fractions of terrestrial OC can fuel microbial respiration and the production of greenhouse gases (Ågren et al. 2008; Battin 2008; Wang et al. 2014). When terrestrial DOC enters aquatic systems, a portion is further mineralized to

CONTACT Joanne K. Heslop jheslop@alaska.edu E Water and Environmental Research Center, University of Alaska Fairbanks, PO Box 5860, Fairbanks, AK 99775, USA.

(4) Supplemental data for this article can be accessed here. 
$\mathrm{CO}_{2}$, which can escape to the atmosphere or be assimilated by plants and algae living in the water (Tao \& Lin 2000; Vonk et al. 2013). Other potential fates of terrestrially derived DOC in aquatic systems are export via transportation, sequestration via flocculation and sedimentation, or bioassimilation by microbes and organisms through aquatic food webs (Cole et al. 2007; McGuire et al. 2010).

Up to 40\% (210-456 Pg C; Strauss et al. 2013; Walter Anthony et al. 2014) of permafrost soil OC is stored in ice-rich loess-dominated soils referred to as yedoma. Formed in unglaciated regions of Siberia, Alaska, and north-west Canada during the late Pleistocene (Solov'ev 1959; Zimov, Schuur et al. 2006; Kanevskiy et al. 2011), yedoma soils are thick $(<50 \mathrm{~m})$ silt-dominated deposits rich $(2-30 \%)$ in OC for mineral soils (Schirrmeister, Grosse et al. 2011). Yedoma is extensive in north-east Siberia, where it underlies an area of over $1000000 \mathrm{~km}^{2}$ and averages $25 \mathrm{~m}$ in thickness (Romanovskij 1993; Zimov, Schuur et al. 2006). Evidence shows yedoma deposits are currently thawing (Romanovsky et al. 2010), but the potential for greenhouse gas production by microbial decomposition of organic matter in thawed yedoma soils has been studied with limited geographic and spatial scope (Zimov et al. 1993; Zimov et al. 1997; Dutta et al. 2006; Walter et al. 2007; Lee et al. 2012; Mann et al. 2012; Knoblauch et al. 2013; Vonk et al. 2013).

Ancient (20,000-35,800 years old) DOC from yedoma soils has found to be more biolabile than Arctic stream, river and permafrost DOC from nonyedoma systems (Vonk et al. 2013; Mann et al. 2014; Drake et al. 2015; Spencer et al. 2015). However, it has been suggested that the OC content of yedoma soils is not evenly distributed across geographic space and stratigraphic layers (Dutta et al. 2006; Zimov, Davydov et al. 2006; Zimov, Schuur et al. 2006; Schirrmeister, Grosse et al. 2011). Respiration rates of ancient (21 700 years old) DOC from a single yedoma outcrop in the Kolyma River Basin, northeast Siberia, were found to be 1.3-1.6 times higher than those of modern DOC collected from different sites in the same yedoma-dominated watershed (Mann et al. 2014). This suggests that location and particular permafrost soil forming processes could affect the magnitude of potential $\mathrm{C}$ release from thawing permafrost. In order to estimate the potential magnitude of gas production from thawing yedoma, the soil OC content of which is geographically variable, it is important to gain a better understanding the potential respiration rates of water-soluble soil OC collected from a wide distribution of sites.

Water-soluble OC derived from soil extracts is representative of the most mobile and labile fractions of soil OC (Ohno et al. 2009; He et al. 2011) which can be readily utilized by microbes (Matzner \&
Borken 2008; Wang et al. 2014). Therefore, in permafrost-dominated regions, examining $\mathrm{C}$ respiration rates from soil extracts collected from a variety of environments with varying amounts of disturbance and available OC provides a useful perspective as to how climate change may alter $\mathrm{C}$ cycling dynamics in these systems. The objective of this study was to quantify the variability of water-soluble soil OC respiration potentials from 16 active layer and thawed shallow $(<1.5 \mathrm{~m})$ permafrost soils from five different landscapes in the Kolyma River Basin, north-east Siberia, Russia using laboratory incubations of soil extracts mixed with river water as a proxy for water-soluble permafrost OC biolability in inland waters. This study was performed as part of the National Science Foundation's Polaris Project, a summer research programme for undergraduate students. Despite a small sample size and limited geographic scope, we hypothesized that the $\mathrm{C}$ respiration potentials of incubated extracts would be directly related to soil OC content and that the OC contents and C respiration potentials would be spatially variable on scales of both stratigraphic layers and geographic locations.

\section{Materials and methods}

\section{Study site and sample collection}

The Kolyma River Basin is the largest Arctic river basin entirely underlain by continuous permafrost, spanning approximately $650000 \mathrm{~km}^{2}$ across northeast Siberia (Vtyurin 1975; Griffin et al. 2011; Holmes et al. 2012). The Kolyma River Basin is largely underlain by yedoma permafrost and the DOC in its rivers shifts from modern $\left(\Delta^{14} \mathrm{C}>100 \%\right.$ o $\mathrm{C}$ in the spring to older $\left(\Delta^{14} \mathrm{C}<0 \%\right.$ ) $\mathrm{C}$ in the fall, suggesting the origin of the DOC transitions from shallow to deeper soils as the active layer seasonally deepens (Neff et al. 2006). We collected soil samples at five sites in the Kolyma River Basin in July 2010 (Table 1, Fig. 1). The sites were selected to be representative of various yedoma-dominated landscapes in the mixed boreal forest region of the Kolyma River watershed. Duvyanni Yar is a yedoma outcrop, about 30-40 m tall, exposed by the Kolyma River through thermokarst and thermoerosion. Shuchi Lake and Tube Dispenser Lake are first generation thermokarst (thaw) lakes formed in thick yedoma permafrost $(>40 \mathrm{~m})$ within $5 \mathrm{~km}$ of the town of Cherskii. The Rodinka soil pit (160 $\mathrm{m}$ asl) was dug in the top of Finish Creek valley on the south-west flank of Rodinka mountain, where the yedoma horizon is relatively thin (ca. $15 \mathrm{~m}$ ), near faded thermokarst and solifluction features. The Bulldozer site refers to a lower elevation slope beneath Rodinka mountain, $60 \mathrm{~m}$ asl. The Bulldozer site is a field of residual 
Table 1. Location, sampling dates, profile delineation method, total depth of profile, depth to the permafrost table and prior observable disturbance at the time of sampling for the soil profiles in this study. See Supplementary Table S1 for surface vegetation cover at each site.

\begin{tabular}{|c|c|c|c|c|c|c|c|}
\hline Site & $\begin{array}{l}\text { Lat. } \\
\text { north }\end{array}$ & $\begin{array}{l}\text { Long. } \\
\text { east }\end{array}$ & $\begin{array}{l}\text { Date sampled } \\
\quad(2010)\end{array}$ & $\begin{array}{l}\text { Profile delineation } \\
\text { method }\end{array}$ & $\begin{array}{l}\text { Profile depth } \\
\text { (cm) }\end{array}$ & $\begin{array}{c}\text { Depth to permafrost } \\
\text { table }(\mathrm{cm})\end{array}$ & Prior surface disturbance \\
\hline $\begin{array}{l}\text { Shuchi Lake } \\
\text { Ridge }\end{array}$ & $68.748^{\circ}$ & $161.384^{\circ}$ & 8 July & Soil pit & 93 & 55 & None \\
\hline Duvyanni Yar & $68.630^{\circ}$ & $159.154^{\circ}$ & 20 July & $\begin{array}{c}\text { Thermokarst } \\
\text { exposure }\end{array}$ & 370 & 35 & None \\
\hline Bulldozer Site & $68.698^{\circ}$ & $161.539^{\circ}$ & 9 July & $\begin{array}{c}\text { Thermokarst } \\
\text { exposure }\end{array}$ & 80 & $-{ }^{\mathrm{a}}$ & $\begin{array}{l}\text { Top } 60-80 \mathrm{~cm} \text { removed by } \\
\text { bulldozer, } 2003\end{array}$ \\
\hline $\begin{array}{l}\text { Tube Dispenser } \\
\text { Lake }\end{array}$ & $68.897^{\circ}$ & $161.407^{\circ}$ & 12 July & Soil pit & 190 & 70 & Thermokarst activity \\
\hline Rodinka & $68.724^{\circ}$ & $161.588^{\circ}$ & 14 July & $\begin{array}{c}\text { Thermokarst } \\
\text { exposure }\end{array}$ & 190 & 103 & $\begin{array}{l}\text { Thermokarst activity and } \\
\text { thermal erosion }\end{array}$ \\
\hline
\end{tabular}

${ }^{a}$ Permafrost table was not reached in this profile.

thermokarst mounds (baydzherakhs) where the surface $4 \mathrm{~m}$ of the soil profile have thawed following bulldozer excavation and removal of the surface organic horizon and active layer $(60-80 \mathrm{~cm})$ in 2003. The surface at our study soil profiles at Duvyanni Yar and Shuchi Lake had not been disturbed previously. In contrast, bulldozer and natural thermokarst activity had removed much of the overlying peat prior to our sampling at the Tube Dispenser Lake, Rodinka and Bulldozer study sites. We report surface vegetation species at each site in Supplementary Table S1. With the exception of the Duvyanni Yar site, none of the sample sites exhibited signs of cryoturbation (Supplementary Fig. S1)

We delineated soil profiles at each sample location from either cross-sectional permafrost exposures or soil pits (Table 1). We determined the thickness of the active layer at these sites by probing to the depth of permafrost at the time of sampling (July), which was prior to the maximum thickness of seasonally thawed active layer (September). Samples to examine soil characteristics (gravimetric soil moisture, bulk density and organic matter content) were collected in ca. $10 \mathrm{~cm}$ intervals at each soil profile. Samples for soil extract chemistry and respiration experiments were collected from four depths along soil profiles representative of different potential regions for soilwater interactions. The top $(10-15 \mathrm{~cm})$ and bottom $(30-50 \mathrm{~cm})$ of the seasonally thawed active layer, determined using July thaw depths, represent regions of near-surface soils which presently experience seasonal freeze-thaw cycles that process and degrade OC. The transient layer $(70-100 \mathrm{~cm})$, consisting of permafrost soils thawed approximately 7000-5000 years ago, during the Holocene thermal optimum that subsequently re-froze under colder climate conditions (Sher et al. 1979; Schirrmeister, Kunitsky et al. 2011), represents near-surface soils that do not thaw seasonally today but may seasonally thaw in a future warmer climate. The presence of massive ice wedges adjacent to our sampling depths indicates that yedoma permafrost sampled at depths greater than $100 \mathrm{~cm}$ below the ground surface and representing older Pleistocene-aged permafrost has not thawed during the Holocene. These samples represent near-surface permafrost soils where the OC has not been previously degraded by freezethaw cycles during the Holocene. The depth of the boundary between the transient layer and yedoma permafrost was determined by assuming the tops of visible ice wedges represented the maximum historic active layer thaw depth at that site. In total we collected 16 (four top active layer, four bottom active layer, four transient layer and four yedoma; Table 2) samples for soil extract chemistry and respiration experiments. Each of these samples was divided into two subsamples and stored (holding time $\leq 10$ days) in the dark at $15^{\circ} \mathrm{C}$ prior to analysis.

\section{Soil characteristics}

We analysed all of the soil characteristics samples $(n=44)$ and one of each soil extract chemistry and respiration experiment subsample pair $(n=16)$ for gravimetric soil moisture, bulk density and organic matter content. Gravimetric water content was determined as the difference in mass between the soil at field moisture and the oven-dried $\left(105^{\circ} \mathrm{C}\right.$ for 48 hours) soil over the mass of the oven-dried soil. Bulk density was measured as the dry soil mass divided by the soil subsample volume. We determined soil organic matter content by calculating the mass difference between the oven-dried and ashed $\left(400^{\circ} \mathrm{C}\right.$ for 4 hours) soil. In our calculations we assumed soil OC content was $50 \%$ of soil organic matter mass (Pribyl 2010). Grain-size distribution was determined using standard hydrometer methods (GOST 2008), with results presented in Supplementary Table S2.

\section{Soil extract chemistry}

Soil extracts were prepared from the second of each respiration experiment soil subsample pair $(n=16)$ 

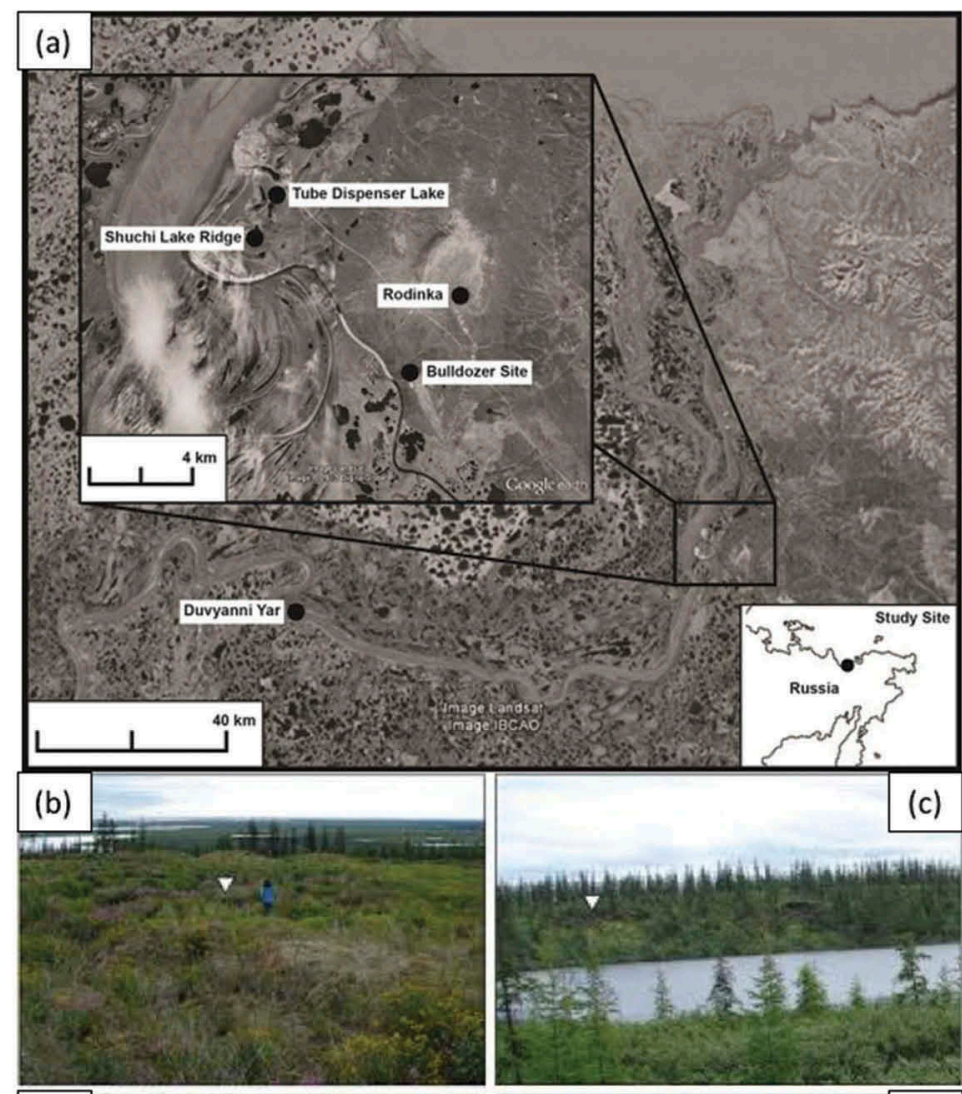

(c)
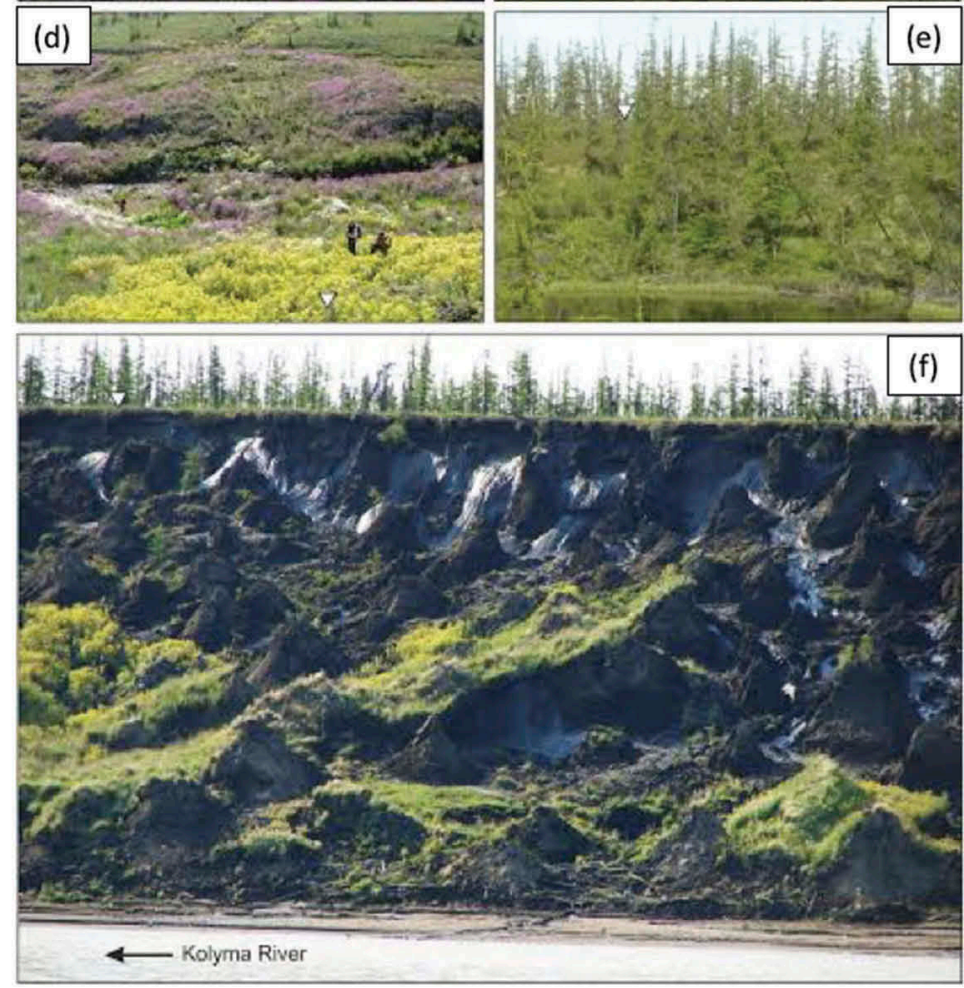

Figure 1. (a) Map showing the five soil sample sites in the Kolyma River Basin, north-east Siberia, Russia, and (b-f) photographs showing locations of the sample sites, marked using white triangles. Surface vegetation data for each site are presented in Supplementary Table S1. (b) The Bulldozer site, located in the Rodinka mountain piedmont, is in a field of residual thermokarst mounds (baydzherakhs) with the Kolyma and Panteleikha rivers floodplain visible in the distance. (c) The Tube Dispenser Lake profile was delineated near exposures of melting ice wedges on the southern slope of the Tube Dispenser Lake, a thermokarst lake. (d) The Rodinka samples, from a site located on the lower slope of Rodinka mountain, were collected near faded thermokarst and solifluction forms in the Finish Creek valley. The flourishing violet, yellow and white flowers indicate the site is in the first succession stadium following completion of active thermokarst and thermal erosion. (e) The Shuchi Lake Ridge site is located within a 'drunken forest,' formed as the yedoma ice complex degrades and sediment slides into the southern wall of the thermokarst Shuchi Lake. (f) The Duvyanni Yar samples were collected from the Duvyanni Yar thermokarst and thermoerosional exposure, cut by the Kolyma River, of the Late Pleistocene ice complex. Photographs by V.V. Spektor. 
Table 2. Soil sample depths, bulk density, field moisture content, OC content, water extractable OC fractions and measured $\mathrm{DOC}, \mathrm{NH}_{4}-\mathrm{N}$ and $\mathrm{PO}_{4}-\mathrm{P}$ concentrations for all soil extracts and Panteleikha River water from different sampling sites and stratigraphic layers in the Kolyma River Basin. Each line in the table represents one soil sample collected and processed as described in the materials and methods section.

\begin{tabular}{|c|c|c|c|c|c|c|c|c|c|}
\hline \multirow[b]{2}{*}{ Sample site } & \multirow[b]{2}{*}{$\begin{array}{c}\text { Stratigraphic } \\
\text { layer }^{\mathrm{a}}\end{array}$} & \multirow[b]{2}{*}{$\begin{array}{l}\text { Depth } \\
(\mathrm{cm})\end{array}$} & \multicolumn{4}{|c|}{ Soil properties } & \multicolumn{3}{|c|}{ Soil extract chemistry } \\
\hline & & & $\begin{array}{l}\text { Dry bulk } \\
\text { density } \\
\left(\mathrm{g} \mathrm{cm}^{-3}\right)\end{array}$ & $\begin{array}{c}\text { Field } \\
\text { moisture } \\
(\%)\end{array}$ & $\begin{array}{c}\mathrm{OC} \\
\text { content } \\
(\%)\end{array}$ & $\begin{array}{c}\text { Fraction water } \\
\text { extractable OC (\%) }\end{array}$ & $\begin{array}{c}\mathrm{DOC} \\
\left(\mathrm{mg} \mathrm{L}^{-1}\right)\end{array}$ & $\begin{array}{c}\mathrm{NH}_{4}-\mathrm{N} \\
\left(\mu \mathrm{g} \mathrm{L}^{-1}\right)\end{array}$ & $\begin{array}{c}\mathrm{PO}_{4}-\mathrm{P} \\
\left(\mu \mathrm{g} \mathrm{L}^{-1}\right)\end{array}$ \\
\hline \multirow[t]{3}{*}{ Shuchi Lake Ridge } & $\mathrm{TAL}$ & 15 & 0.78 & 35 & 13.0 & 0.33 & 27.85 & $-{ }^{b}$ & $-{ }^{b}$ \\
\hline & BAL & 50 & 0.60 & 18 & 1.5 & 0.45 & 5.55 & 24.83 & 33.79 \\
\hline & $\mathrm{TL}$ & 90 & 0.45 & 19 & 1.5 & 0.23 & 2.82 & 2608 & 36.67 \\
\hline \multirow{4}{*}{ Duvyanni Yar } & $\mathrm{TAL}$ & 15 & 0.97 & 65 & 20.5 & 0.27 & 19.15 & 118.0 & 7.29 \\
\hline & BAL & 35 & 0.49 & 22 & 2.5 & 0.15 & 3.01 & 255.1 & 59.30 \\
\hline & $\mathrm{TL}$ & 70 & 0.22 & 48 & 4.0 & 1.06 & 22.11 & 360.0 & 23.47 \\
\hline & PP & 150 & 0.56 & 36 & 2.5 & 1.02 & 16.37 & 4573 & 10.26 \\
\hline Bulldozer site & $\mathrm{PP}$ & 80 & 0.82 & 10 & 1.5 & 0.68 & 9.13 & 74.11 & 47.49 \\
\hline \multirow[t]{4}{*}{ Tube Dispenser Lake } & TAL & 10 & 0.74 & 24 & 1.0 & 1.19 & 9.03 & 87.30 & $\mathrm{BDL}^{\mathrm{c}}$ \\
\hline & $\mathrm{BAL}$ & 30 & 0.74 & 24 & 1.0 & $-\mathrm{b}$ & $-{ }^{\mathrm{b}}$ & $-{ }^{b}$ & $-{ }^{b}$ \\
\hline & $\mathrm{TL}$ & 70 & 0.74 & 47 & 1.5 & $-{ }^{b}$ & $-{ }^{b}$ & $-{ }^{\mathrm{b}}$ & 28.61 \\
\hline & PP & 110 & 0.35 & 36 & 1.5 & 0.84 & 8.10 & 249.8 & 90.37 \\
\hline \multirow[t]{4}{*}{ Rodinka } & TAL & 15 & 0.75 & 12 & 2.5 & 0.23 & 5.08 & $-{ }^{b}$ & $-{ }^{b}$ \\
\hline & BAL & 40 & 0.67 & 20 & 2.5 & 0.36 & 7.28 & 81.95 & 22.88 \\
\hline & $\mathrm{TL}$ & 100 & 0.70 & 38 & 2.5 & 1.78 & 27.66 & $-\mathrm{b}$ & 28.61 \\
\hline & PP & 120 & 1.04 & 38 & 3.0 & 1.40 & 25.95 & 533.4 & 22.57 \\
\hline Panteleikha River & River water & Ca. 100 & $\mathrm{~N} / \mathrm{A}$ & $\mathrm{N} / \mathrm{A}$ & $\mathrm{N} / \mathrm{A}$ & $\mathrm{N} / \mathrm{A}$ & 4.83 & 50.00 & 310.0 \\
\hline
\end{tabular}

${ }^{a}$ TAL: top active layer; BAL: bottom active layer; TL: transient layer; PP: Pleistocene permafrost. ${ }^{\mathrm{b}}$ Parameter was not measured.

by vigorously mixing a $100 \mathrm{~g}$ subsample of soil at field moisture with $1 \mathrm{~L}$ deionized water for $30 \mathrm{~min}$ utes. The extract was filtered through a precombusted $\left(450^{\circ} \mathrm{C}\right.$ for 4 hours) glass microfibre filter $(0.7 \mu \mathrm{m}$, Whatman $\mathrm{GF} / \mathrm{F}$ ) to remove particulate organic matter and analysed for ammonium $\left(\mathrm{NH}_{4}-\mathrm{N}\right.$; detection limit $5 \mu \mathrm{g} \mathrm{L}^{-1}$ ) using a fluorometric method (Taylor et al. 2007) and soluble reactive phosphorous $\left(\mathrm{PO}_{4}-\mathrm{P}\right.$; detection limit $10 \mu \mathrm{g} \mathrm{L}^{-1}$ ) using the molybdenumblue method (Rigler 1966). DOC content was quantified using a Shimadzu TOC-V using established protocols (Mann et al. 2012). We calculated the fraction of water soluble OC as the ratio between the mass of DOC extracted and the mass of total OC in the bulk soil utilized to make the extract.

\section{Respiration experiments}

We conducted heterotrophic respiration experiments on permafrost soil extracts mixed with water from the Panteleikha River as a proxy for water-soluble OC bioavailability in inland waters. The Panteleikha River drains an area of $1500 \mathrm{~km}^{2}$ and is a tributary to the Kolyma River. Panteleikha River water was obtained from about $1 \mathrm{~m}$ depth on 27 July 2010. We analysed a subsample of river water for DOC, $\mathrm{NH}_{4}-\mathrm{N}$ and $\mathrm{PO}_{4}-\mathrm{P}$ using the methods described in the previous section. Respiration potentials were measured by incubating $60 \mathrm{ml}$ of the prepared soil extract with $240 \mathrm{ml}$ of unfiltered Panteleikha River water within standard $300 \mathrm{ml}$ BOD bottles (Wheaton). Duplicate experimental incubation vials were prepared for each of the 16 soil extract samples. Two BOD bottles containing $300 \mathrm{ml}$ unfiltered Panteleikha River water were prepared as an experimental control. All incubation vials were tightly sealed and maintained in the dark at $20^{\circ}$
$\mathrm{C}$, the approximate temperature of the Panteleikha River's near-surface water in July.

We calculated biological oxygen $\left(\mathrm{O}_{2}\right)$ demand using standard methods as the loss of dissolved $\mathrm{O}_{2}$ over a five-day period (Greenberg et al. 1992). We determined dissolved $\mathrm{O}_{2}$ concentrations in the bottles using a benchtop BOD $\mathrm{O}_{2}$ probe (YSI 556; accuracy \pm $0.2 \mathrm{mg} \mathrm{L}^{-1}$ ); none of the bottles reached anoxia within the five-day period. Oxygen consumption was converted to $\mathrm{C}$ respiration by assuming that all dissolved $\mathrm{O}_{2}$ loss was due to aerobic respiration and each unit loss in $\mathrm{O}_{2}$ corresponded to a unit production of carbon dioxide $\left(\mathrm{CO}_{2}\right)$. The calculated $\mathrm{CO}_{2}$ production over the incubation period was multiplied by the ratio of carbon's atomic mass to oxygen's atomic mass (0.375) to determine the mass of $\mathrm{C}$ respired in each incubation vial.

We report the $\mathrm{C}$ respiration of each sample in terms of: total $\mathrm{C}$ respired $(\mathrm{mg})$, net $\mathrm{C}$ respired from the soil extract $(\mathrm{mg})$, the mass of $\mathrm{C}$ respired per gram soil OC (mg C g OC ${ }^{-1}$ ) and the fraction of total DOC respired (\%). Total C respiration from the BOD bottle is reported as cumulative $\mathrm{C}$ respired from both the river water and the soil extracts during the five-day BOD incubation period. Net C respiration from the soil extract is reported as the total $\mathrm{C}$ respiration from the BOD bottle minus the mean $C$ respiration measured in the river water controls. The mass of $\mathrm{C}$ respired per gram soil OC was calculated by dividing the net $\mathrm{C}$ respiration from the soil extract by the mass of OC in the soil used to prepare the extract. We calculated the fraction of DOC respired by dividing the total C respiration by the measured amount of total DOC within the BOD bottle. All respiration data are 
presented as mean \pm SE together with a reported sample size, where $n$ represents the number of soil extract samples. An $n$ value of 1 represents the mean of duplicate laboratory incubation vials containing extract from a single field soil sample.

\section{Statistics}

All statistical analyses were conducted using MATLAB (R2013a Student Version) software. Soil OC contents and all soil extract data $\left(\mathrm{NH}_{4}-\mathrm{N}, \mathrm{PO}_{4}{ }^{-}\right.$ $\mathrm{P}, \mathrm{DOC}$, net $\mathrm{C}$ respiration, $\mathrm{C}$ respiration $\mathrm{g}$ soil $\mathrm{OC}^{-1}$, $\%$ DOC respired) were tested for normal distribution using the Jarque-Bera test. The data for DOC, net C respiration and \% DOC respired were found to be consistent with a normal distribution at the $\alpha=0.05$ level. Data for soil OC, soil extract $\mathrm{NH}_{4}-\mathrm{N}$ and $\mathrm{PO}_{4}-\mathrm{P}$ concentrations, and $\mathrm{C}$ respiration $\mathrm{g}$ soil $\mathrm{OC}^{-1}$ were not consistent with a normal distribution at the $\alpha=0.05$ level; these variables were log-transformed to improve normality. Since half of our data parameters were found to be inconsistent with a normal distribution, we determined the statistical significance of differences in soil OC and extract parameters between soil layers and sampling sites using the nonparametric Mann-Whitney U-test. We determined all correlations using Spearman's rank correlation coefficients. Both the differences and correlations were considered statistically significant when $p \leq 0.05$ ( $\alpha=0.05$ confidence level). Finally, we conducted forward stepwise multiple linear regressions to examine how well our tested soil $(\log [\mathrm{OC}])$ and extract (DOC, $\log \left[\mathrm{NH}_{4}-\mathrm{N}\right], \log \left[\mathrm{PO}_{4}-\mathrm{P}\right]$ ) parameters predicted the measured $\mathrm{C}$ respiration (net $\mathrm{C}$ respiration, $\log \left[\mathrm{C}\right.$ respiration $\mathrm{g}$ soil $\left.\mathrm{OC}^{-1}\right]$ and $\%$ DOC respired). Terms were added to the stepwise regression models using the standard SSE criterion.

\section{Results}

\section{Soil characteristics}

Soil dry bulk density ranged from $0.21-1.13 \mathrm{~g} \mathrm{~cm}^{-3}$ (median $0.70 \mathrm{~g} \mathrm{~cm}^{-3}$, mean $0.67 \pm 0.23 \mathrm{~g} \mathrm{~cm}^{-3}$, $n=44)$ and gravimetric water content ranged from 7.2 to $70.7 \%$ moisture (median $24.0 \%$, mean $28.1 \pm 16.7 \%, n=45$; Supplementary Fig. S2). Soil bulk OC content ranged from 1 to $20.5 \%$ by mass (median 1.7\%, mean $2.7 \pm 3.3 \%$ OC, $n=46$ ). Soils from Duvyanni Yar (1.7-20.3\% OC, median 2.9\%, mean $4.9 \pm 5.5 \%, n=11)$ and Shuchi Lake Ridge (1.2-12.9\% OC, median $1.2 \%$, mean $2.7 \pm 4.1 \%$, $n=8$ ), the two sites which had not experienced prior disturbance, had higher levels of bulk soil OC ( $p=0.021$ and 0.001 , respectively) compared to other sampling sites. There were no additional statistically significant differences in soil characteristics between sampling sites or soil stratigraphic layers.

\section{River water and soil extract chemistry}

River water from the Panteleikha River had initial nutrient concentrations of $50.0 \pm 5 \mu \mathrm{g} \mathrm{L} \mathrm{L}^{-1} \mathrm{NH}_{4}-\mathrm{N}$, $310.0 \pm 10 \mu \mathrm{g} \mathrm{L}^{-1} \mathrm{PO}_{4}-\mathrm{P}$, and $4.83 \mathrm{mg} \mathrm{L}^{-1} \mathrm{DOC}$ (Table 2). Ammonium $\left(\mathrm{NH}_{4}-\mathrm{N}\right)$ concentrations extracted from the soil samples ranged from 24.8 to $4573 \mu \mathrm{g} \mathrm{L} \mathrm{L}^{-1} \mathrm{NH}_{4}-\mathrm{N}$ (median $250 \mu \mathrm{g} \mathrm{L} \mathrm{L}^{-1}$, mean $\left.747 \pm 437 \mu \mathrm{g} \mathrm{L}{ }^{-1}, n=11\right)$. Extracted soluble reactive phosphorous $\left(\mathrm{PO}_{4}-\mathrm{P}\right)$ concentrations ranged from 7.3 to $90.4 \mu \mathrm{g} \mathrm{L}^{-1} \mathrm{PO}_{4}-\mathrm{P}$ (median $28.6 \mu \mathrm{g} \mathrm{L} \mathrm{L}^{-1}$, mean $\left.31.7 \pm 6.4 \mu \mathrm{g} \mathrm{L}^{-1}, n=12\right)$. DOC concentrations in the soil extract varied by an order of magnitude, ranging from 2.8 to $27.9 \mathrm{mg} \mathrm{L}^{-1}$ (median $9.1 \mathrm{mg} \mathrm{L}^{-1}$, mean $13.5 \pm 2.5 \mathrm{mg} \mathrm{L}^{-1}, n=14$ ). Soils with higher OC contents extracted more DOC $(r=0.58, p=0.029)$. Fractions of water soluble OC in our extracts ranged from 0.15 to $1.78 \%$ (median $0.57 \%$, mean $0.71 \pm 0.14 \%$ OC, $n=14)$. There were no statistically significant differences in soil extract chemistry between sampling sites or soil stratigraphic layers. Full river water and soil extract chemistry results are shown in Table 2.

\section{Carbon respiration}

Total $\mathrm{C}$ respiration during the five-day incubation period ranged from 0.17 to $0.67 \mathrm{mg} \mathrm{C}$ (median $0.28 \mathrm{mg}$, mean $0.33 \pm 0.08 \mathrm{mg}, n=16$; Table 3 ). The fraction of total DOC (river water DOC plus soil extract DOC) respired during the incubation period ranged from 8.9 to $31.4 \%$ (median $17.8 \%$, mean $18.2 \pm 1.7 \%, n=14)$. Soil extract respiration ranged from -0.03 to $0.47 \mathrm{mg} \mathrm{C}$ (median $0.08 \mathrm{mg}$, mean $0.13 \pm 0.08 \mathrm{mg}, n=16)$ and -0.42 to $5.21 \mathrm{mg} \mathrm{C}$ g soil $\mathrm{OC}^{-1}$ (median $0.62 \mathrm{mg} \mathrm{C} \mathrm{g} \mathrm{soil} \mathrm{OC}^{-1}$, mean $1.32 \pm 1.77 \mathrm{mg} \mathrm{C}$ g soil $\left.\mathrm{OC}^{-1}, n=16\right)$. Extract samples from the Shuchi Lake Ridge bottom active layer, Duvyanni Yar bottom active layer and Tube Dispenser Lake transitional layer respired less $C$ than the river water control. Overall, the bottom active layer had lower $\mathrm{C}$ respiration potentials (total $\mathrm{C}$ respired and $C$ respired from soil extract) than the other stratigraphic layers ( $p=0.012$ for both; Fig. 2). There were no statistically significant differences in $\mathrm{C}$ respiration between sampling sites (Supplementary Fig. S3). Full $\mathrm{C}$ respiration results are shown in Table 3.

Correlation analyses did not show any statistically significant relationships between $\mathrm{C}$ respiration, soil $\mathrm{OC}$ contents and extract DOC, $\mathrm{NH}_{4}-\mathrm{N}$ or $\mathrm{PO}_{4}-\mathrm{P}$ concentrations. Forward stepwise multiple linear regression analyses revealed that the mass of soil extract $\mathrm{C}$ respired $(\mathrm{mg})$ and the fraction of total DOC respired (\%) could be estimated by the log- 
Table 3. Mass of initial DOC in the BOD bottles, the initial DOC partitioning between soil extract DOC and river water DOC, the amount of carbon $(C)$ respired during the five-day incubation $\pm S E$ between duplicate bottles, $C$ respired from the soil extracts (net $C$ respiration - river water control), $C$ respired per g soil OC (C respired from soil extract/mass soil OC used to make the extract), the fraction of total DOC (river DOC + extract DOC) respired and the effect of the soil extract on C respiration. The effect of the soil extract on $C$ respiration was determined as positive $(+)$ or negative $(-)$ when $C$ respiration from the soil extracts was higher or lower than the river water control, respectively.

\begin{tabular}{|c|c|c|c|c|c|c|c|c|c|}
\hline \multirow[b]{2}{*}{ Sample site } & \multirow[b]{2}{*}{$\begin{array}{c}\text { Stratigraphic } \\
\text { layer }^{\mathrm{a}}\end{array}$} & \multicolumn{3}{|c|}{ DOC } & \multicolumn{5}{|c|}{$\mathrm{C}$ respiration } \\
\hline & & $\begin{array}{c}\text { DOC } \\
\text { contribution } \\
\text { from soil } \\
\text { extract (mg } \\
\text { C) }\end{array}$ & $\begin{array}{c}\text { DOC } \\
\text { contribution } \\
\text { from river } \\
\text { water (mg C) }\end{array}$ & $\begin{array}{l}\text { Net initial } \\
\text { DOC in } \\
\text { BOD bottle } \\
\text { (mg C) }\end{array}$ & $\begin{array}{l}\text { Total C } \\
\text { respired in } \\
\text { BOD bottle } \\
(\mathrm{mg} \mathrm{C})\end{array}$ & $\begin{array}{l}\text { C respired } \\
\text { from soil } \\
\text { extract } \\
(\mathrm{mg} \mathrm{C})\end{array}$ & $\begin{array}{c}C \text { respired } \\
\text { per g soil } \\
\mathrm{OC}\left(\mathrm{mg} \mathrm{Cg}^{-1} \mathrm{~g}\right. \\
\left.\mathrm{OC}^{-1}\right)\end{array}$ & $\begin{array}{c}\text { Fraction of } \\
\text { total DOC } \\
\text { respired } \\
(\%)\end{array}$ & $\begin{array}{l}\text { Effect of } \\
\text { soil extract } \\
\text { on C } \\
\text { respiration }\end{array}$ \\
\hline Panteleikha River & River water & N/A & 1.45 & 1.45 & $0.20 \pm 0.01$ & N/A & $\mathrm{N} / \mathrm{A}$ & 13.82 & N/A \\
\hline \multirow[t]{3}{*}{ Shuchi Lake Ridge } & $\mathrm{TAL}$ & 1.67 & 1.16 & 2.83 & $0.50 \pm 0.05$ & 0.30 & 0.59 & 17.48 & + \\
\hline & BAL & 0.33 & 1.16 & 1.49 & $0.17 \pm 0.02$ & -0.03 & -0.41 & 11.34 & - \\
\hline & $\mathrm{TL}$ & 0.17 & 1.16 & 1.33 & $0.35 \pm 0.03$ & 0.15 & 2.06 & 26.02 & + \\
\hline \multirow[t]{4}{*}{ Duvyanni Yar } & TAL & 1.15 & 1.16 & 2.31 & $0.44 \pm 0.02$ & 0.24 & 0.56 & 19.17 & + \\
\hline & BAL & 0.18 & 1.16 & 1.34 & $0.19 \pm 0.00$ & -0.01 & -0.09 & 14.05 & - \\
\hline & $\mathrm{TL}$ & 1.33 & 1.16 & 2.49 & $0.45 \pm 0.03$ & 0.25 & 2.00 & 18.12 & + \\
\hline & PP & 0.98 & 1.16 & 2.14 & $0.67 \pm 0.27$ & 0.47 & 4.90 & 31.35 & + \\
\hline Bulldozer site & $\mathrm{PP}$ & 0.55 & 1.16 & 1.71 & $0.24 \pm 0.01$ & 0.04 & 0.50 & 14.33 & + \\
\hline \multirow[t]{4}{*}{ Tube Dispenser Lake } & TAL & 0.54 & 1.16 & 1.70 & $0.36 \pm 0.01$ & 0.16 & 3.51 & 20.99 & + \\
\hline & BAL & $-{ }^{\mathrm{b}}$ & 1.16 & $-{ }^{b}$ & $0.24 \pm 0.01$ & 0.04 & 0.88 & $-{ }^{\mathrm{b}}$ & + \\
\hline & $\mathrm{TL}$ & $-{ }^{b}$ & 1.16 & $-{ }^{b}$ & $0.18 \pm 0.01$ & -0.02 & -0.42 & $-{ }^{\mathrm{b}}$ & - \\
\hline & PP & 0.49 & 1.16 & 1.65 & $0.50 \pm 0.02$ & 0.30 & 5.21 & 30.28 & + \\
\hline \multirow[t]{4}{*}{ Rodinka } & TAL & 0.30 & 1.16 & 1.46 & $0.30 \pm 0.09$ & 0.10 & 0.76 & 20.62 & + \\
\hline & BAL & 0.44 & 1.16 & 1.60 & $0.20 \pm 0.01$ & 0.00 & 0.00 & 12.82 & -- \\
\hline & $\mathrm{TL}$ & 1.66 & 1.16 & 2.82 & $0.26 \pm 0.13$ & 0.06 & 0.66 & 9.28 & + \\
\hline & PP & 1.56 & 1.16 & 2.72 & $0.24 \pm 0.02$ & 0.04 & 0.36 & 8.86 & + \\
\hline
\end{tabular}

${ }^{\text {a }}$ TAL: top active layer; BAL: bottom active layer; TL: transient layer; PP: Pleistocene permafrost. ${ }^{b}$ Parameter was not measured. ${ }^{c}+$ increased respiration; - suppressed respiration; - - no change.
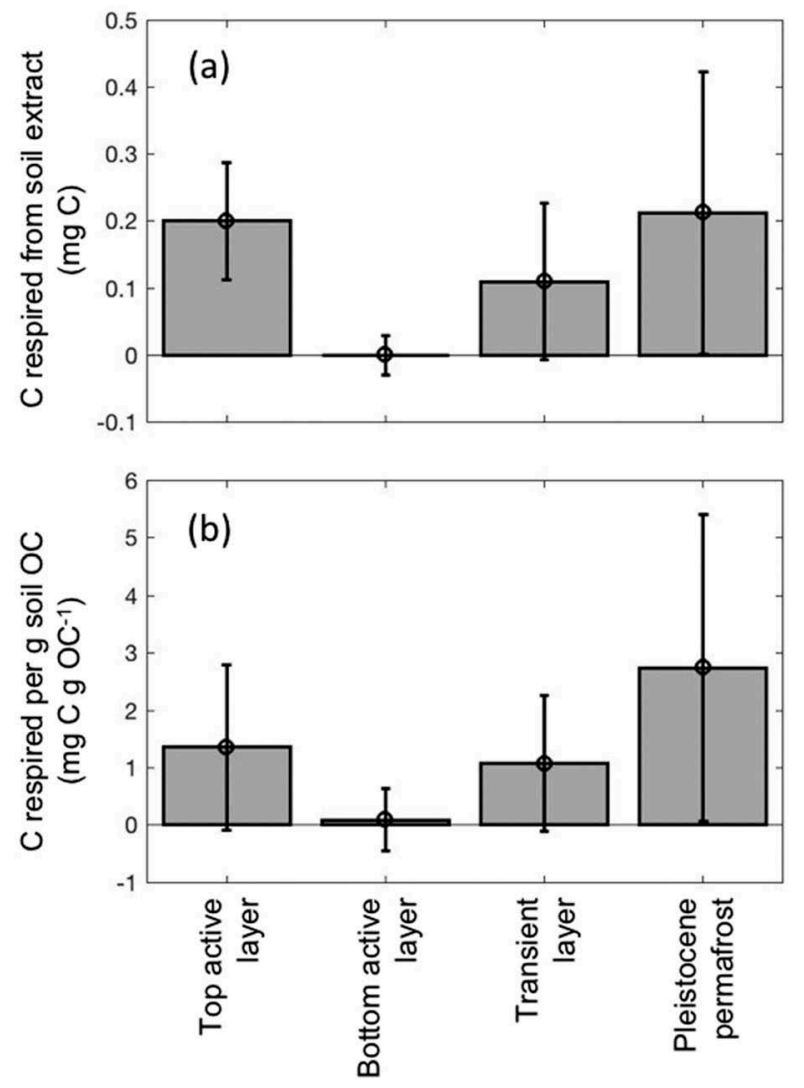

Figure 2. (a) Carbon respiration separated by site and (b) by stratigraphic layer. The top graphs show the mass of $C$ respired from the soil extracts $(\mathrm{mg} \mathrm{C})$; the middle graphs show the mass of $\mathrm{C}$ respired per $\mathrm{g}$ soil $\mathrm{OC}\left(\mathrm{mg} \mathrm{C} \mathrm{g} \mathrm{OC}^{-1}\right)$; the bottom graphs show the fraction of total DOC respired during the five-day incubation period (\%). transformed $\mathrm{NH}_{4}-\mathrm{N}$ concentrations in the soil extracts ( $p=0.046$ and 0.043 , respectively; Table 4$)$. Carbon respiration in terms of $\mathrm{C}$ respired per $\mathrm{g}$ soil OC was not predicted by any measured parameters in the final linear model. Complete data for the linear regression models are presented in Table 4.

\section{Discussion}

Our results indicate that soils in the Kolyma River Basin, north-east Siberia, are spatially variable in terms of soil OC content. Soils from Duvyanni Yar and Shuchi Lake Ridge had significantly $(p<0.05)$ higher OC contents compared to the other sampled sites. We hypothesize this is because much of the surface vegetation has remained undisturbed, allowing modern plants and roots to provide greater fresh OC input at these two sites. The observed variance in yedoma (Pleistocene permafrost) OC content across sites (1.5-3.0\% OC) suggests that soil OC is unevenly distributed across the yedoma-permafrost-dominated landscape. This outcome would be expected given that, even within a single site, soil OC content can vary by an order of magnitude throughout the vertical profile of tens of metres because of palaeoenvironmental differences during the Pleistocene and Holocene (Tarnocai et al. 2009; Schirrmeister et al. 2011a).

Samples collected from the bottom active layer had lower mean $C$ respiration rates than the other stratigraphic layers in our study $(p=0.012)$. Soils in the 
Table 4. Results from forward stepwise multiple linear regression analyses examining $C$ respiration as the response variable in terms of soil extract $C$ respired $(\mathrm{mg}), \mathrm{C}$ respired per gram soil $\mathrm{OC}\left(\mathrm{mg} \mathrm{C} \mathrm{g} \mathrm{OC}^{-1}\right)$ and the fraction total DOC respired (\%). Soil $\mathrm{OC}$ contents and soil extract $\mathrm{DOC}$ and $\log \left(\mathrm{PO}_{4}-\mathrm{P}\right)$ concentrations did not predict $\mathrm{C}$ respiration in any model. Soil extract $\log \left(\mathrm{NH}_{4}-\mathrm{N}\right)$ concentrations predicted $\mathrm{C}$ respiration in terms of soil extract $\mathrm{C}$ respired $(\mathrm{mg})$ and the fraction total DOC respired (\%). Carbon respiration per gram soil OC had no significant predictor variables in the final regression model.

\begin{tabular}{|c|c|c|c|c|}
\hline \multirow[b]{2}{*}{ Parameter } & & \multicolumn{3}{|c|}{$C$ respiration } \\
\hline & & $\begin{array}{l}\text { Soil extract } \mathrm{C} \\
\text { respired }(\mathrm{mg} \mathrm{C})\end{array}$ & $\begin{array}{l}C \text { respired per g soil } \mathrm{OC} \\
\left(\mathrm{mg} \mathrm{C} \mathrm{g} \mathrm{OC}^{-1}\right)\end{array}$ & $\begin{array}{l}\text { Fraction total DOC } \\
\text { respired (\%) }\end{array}$ \\
\hline \multirow[t]{3}{*}{$\beta_{0}$ (Intercept) } & Value & -0.760 & 1.149 & 0.502 \\
\hline & SE & 0.545 & 0.085 & 7.811 \\
\hline & $p$ & 0.201 & 0.113 & 0.950 \\
\hline \multirow[t]{3}{*}{$\beta_{1}\left(\log \left[\mathrm{NH}_{4}-\mathrm{N}\right]\right)$} & Value & 0.221 & $-{ }^{\mathrm{b}}$ & 3.225 \\
\hline & $p$ & 0.046 & $-{ }^{\mathrm{b}}$ & 0.043 \\
\hline & SE & 0.094 & $-{ }^{\mathrm{b}}$ & 1.341 \\
\hline \multirow[t]{4}{*}{ Regression model } & $\mathrm{df}$ & 8 & 9 & 8 \\
\hline & RMSE $^{\mathrm{a}}$ & 0.45 & 0.27 & 6.46 \\
\hline & $R^{2}$ & 0.411 & $-^{c}$ & 0.420 \\
\hline & $p$ & 0.046 & $-^{c}$ & 0.043 \\
\hline
\end{tabular}

${ }^{\mathrm{a}}$ Root mean square error. ${ }^{\mathrm{b}}$ Parameter was not in final regression model. ${ }^{\mathrm{c}}$ No parameters were significant $(p \leq 0.05)$ in final regression model.

bottom active layer currently experience seasonal freeze-thaw cycles, which degrades soil OC and promotes increased water-soluble OC release (Wang et al. 2014). Although soils in the top active layer also experience annual freezing and thawing, the top active layer receives inputs of fresh, labile OC from modern plants which are densely rooted in this layer, while soils in the bottom active layer presumably receive lower inputs of fresh organic matter from modern plants. In addition, deeper active layer depths in late summer cause increased water residence times in the bottom active layer compared to the top active layer, which increases soil-water interaction and can potentially facilitate OC dissolution and export (Neff et al. 2006; Wickland et al. 2007; Frey \& McClelland 2009). However, it is important to note that in natural systems this process is highly watershed-dependent and, depending on local environmental and permafrost conditions, increased soil-water interaction can also lead to the sorption of DOC to mineral soils (McDowell \& Wood 1984; Neff \& Asner 2001; Frey \& McClelland 2009).

The $\mathrm{C}$ respiration rates of shallow yedoma (Pleistocene silt-dominated permafrost) in our study were highly variable by site. The yedoma soil extract from Duvyanni Yar respired 3.4 times more C than the averaged yedoma extracts from the Tube Dispenser Lake, Rodinka and Bulldozer sites, although its soil OC content was on average only 1.3 times higher. This suggests that the yedoma OC was more bioavailable at the Duvyanni Yar site and yedoma organic matter quality is not homogeneous across the Kolyma River Basin, which concurs with the findings of Mann et al. (2014) concerning the spatial variability of DOC biolability in the same watershed. We did not observe statistically significant differences in $\mathrm{C}$ respiration potentials when comparing the transient layer and the yedoma. We had hypothesized that extracts from the transient layer would respire less $\mathrm{C}$ than extracts from the Pleistocene permafrost because the most labile fractions of its OC pool had been previously degraded by freeze-thaw cycles and microbial respiration during the Holocene thermal optimum (Sher et al. 1979; Schirrmeister et al. 2011b; Vonk et al. 2013; Wang et al. 2014). While the lack of a statistically significant difference in $\mathrm{C}$ respiration rates may be due to our small sample size, it is also possible that near-surface yedoma with the potential to thaw from deepening active layer thicknesses may not have significantly higher proportions of bioavailable OC when compared to the overlying shallow transient layer permafrost.

We observed lower respiration rates in $25 \%$ of vials containing soil extracts compared to the control vials containing only river water (Table 3), suggesting that the soil extracts in these samples may contain inhibitory organic compounds that reduce DOC decomposition in aquatic systems. For instance, phenolic compounds have been found to inhibit both bacterial abundance and microbial metabolism, even in the presence of high OC and nutrients (Fenner \& Freeman 2011; Mann et al. 2014). While we did not measure OC composition or quality in our study, these results suggest soil OC composition must also be taken into account when estimating potential $\mathrm{C}$ respiration potentials from recently thawed permafrost.

Previous studies have shown that permafrost disturbance, including thermokarst activity, can export large amounts of labile DOC to inland waters (Vonk et al. 2013; Abbott et al. 2014). However, in our study there were no statistically significant differences in C 
respiration between previously undisturbed profiles (Duvyanni Yar and Shuchi Lake Ridge) and sites where the surface had been previously disturbed (Bulldozer Site, Tube Dispenser Lake, Rodinka). This is consistent with findings by Larouche et al. (2015), which showed that labile DOC fractions in Alaskan inland waters were not significantly altered by disturbance. Previously undisturbed sites in our study had higher OC contents in their profiles, and higher OC contents in bulk soil samples positively correlated with higher DOC levels in our soil extracts $(r=0.58, p=0.029)$. Although the fractions of watersoluble OC in our soil samples were low (0.15$1.78 \%)$, the proportions of soil OC extracted in our study were consistent with general proportions of water-extractable soil organic matter in total soil organic matter (2-5\%; Ellerbrock et al. 1999; He et al. 2011). While higher soil OC contents correlated with higher DOC concentrations in our soil extracts, higher extract DOC concentrations did not lead to higher $\mathrm{C}$ respiration potentials and soil extract $\mathrm{C}$ respiration potentials did not correlate with soil OC contents in our study. Our finding that higher extract DOC concentrations did not necessarily yield higher $\mathrm{C}$ respiration potentials contradicts previous studies in which higher DOC concentrations in inland waters led to increased release of $\mathrm{CO}_{2}$ (Algesten et al. 2005; Battin et al. 2008; Lapierre et al. 2013).

One possible explanation is that $\mathrm{C}$ respiration in our study is limited by an alternative factor other than DOC concentrations. For instance, macronutrient availability, organic matter composition and microbial communities within our incubations may have influenced extract $C$ respiration rates observed in this study. Prior studies have found that landscapescale variation in soil $\mathrm{C}$ bioavailability can be linked to soil $\mathrm{C}$ to $\mathrm{N}$ ratios, with higher values leading to more C respiration (Schuur et al. 2015). In aquatic systems, nutrient concentrations and ratios in the environment could limit $\mathrm{C}$ respiration when they deviate from the Redfield ratio (16 N: $1 \mathrm{P}$ ) or microbial N:P biomass ratios (7 N: 1 P; Cleveland \& Liptzin 2007). Previous studies in Arctic aquatic ecosystems found bacterial production is usually limited by phosphorous (Granéli et al. 2004; Hobbie \& LaybournParry 2008), but we did not find a statistically significant positive relationship between extract $\mathrm{C}$ respiration potentials and $\mathrm{PO}_{4}-\mathrm{P}$ concentrations in our study. Our multiple linear regression analyses indicated positive correlation between $\mathrm{C}$ respiration and ammonium $\left(\mathrm{NH}_{4}-\mathrm{N}\right)$ concentrations in the soil extracts, suggesting potential $\mathrm{N}$ limitation in our system. However, since ammonium is only a fraction of the total $\mathrm{N}$ pool, we are unable to determine if there is significant correlation between $\mathrm{C}$ respiration and $\mathrm{C}$ to $\mathrm{N}$ ratios in our study.
Approximately $8.9-31.2 \%$ of the total DOC in our incubation vials was respired during our five-day incubation period. This is consistent with several prior laboratory incubations which found that only $4-60 \%$ of DOC from soils is available for microbial respiration (Kalbitz et al. 2003; Holmes \& McClelland 2008; Vonk et al. 2013; Larouche et al. 2015; Spencer et al. 2015). While we acknowledge the limitations of using laboratory incubations to extrapolate what proportion of water-soluble soil OC will be respired upon entering inland waters, we note that our incubation period (five days) is consistent with mean residence times it takes water to move from permafrost thaw sites to the Kolyma River main stem (three to seven days; Vonk et al. 2013). In the Kolyma River Basin and other inland water sites, the proportion of soil OC available for microbial respiration and, by extension, the soil's net $\mathrm{C}$ respiration potential, increases as initial processing and breakdown by ultraviolet light makes OC compounds more bioavailable for heterotrophic respiration and the production of $\mathrm{CO}_{2}$ (Cory et al. 2013). Other studies suggest up to $22 \%$ of DOC can be sequestered by reactive iron and thus made unavailable for $\mathrm{C}$ respiration (Salvadó et al. 2015). Therefore, further research is necessary to understand the full $\mathrm{C}$ respiration potential of water-soluble OC from the Kolyma River yedoma region's thawing permafrost as it is processed in situ.

\section{Conclusions}

Examining soil OC quantity and quality can lead to a better understanding of how much soil $\mathrm{C}$ can be immediately processed following permafrost thaw and watersoluble OC release to inland waters. Our study indicates that while soil OC content is spatially variable in the Kolyma River Basin it is not necessarily an indicator of $\mathrm{C}$ respiration potentials upon permafrost thaw and export to inland waters. Sites which had not experienced prior disturbance had higher soil OC contents, but there were no statistically significant differences in $\mathrm{C}$ respiration potentials between disturbed versus undisturbed sites in our study. This suggests that alternative OC quality parameters, including exposure to freeze-thaw cycling, the extent of seasonal interactions with water and the presence of inhibitory organic compounds, may also play a role in watersoluble $\mathrm{C}$ respiration potentials. It is also important to consider factors which may alter in situ $\mathrm{C}$ respiration from thawing permafrost, such as DOC sorption to mineral soils and the additional physical procession DOC experiences after being released to inland waters, when estimating the true magnitude of $\mathrm{C}$ release from thawing permafrost soils. 


\section{Acknowledgements}

This study was supported by the National Science Foundation as part of the Polaris Project (NSF-0732586 and NSF-0732944). Additional support for JKH and KMWA came from NSF-1107892 and NASANNX11AH20G. We would like to thank E. Bulygina, A. Bunn, R.M. Holmes, P. Mann, J. Schade, N. Zimov and S. Zimov for assisting with data collection and/or project organization. We thank the anonymous reviewers for their detailed comments, which greatly assisted in improving the manuscript. An earlier version of this manuscript benefitted from reviews from B. Abbott and C. Griffin.

\section{Disclosure statement}

No potential conflict of interest was reported by the authors.

\section{Funding}

This work was supported by the National Aeronautics and Space Administration (NSF-0732586; NSF-0732944; NSF1107892; NASA-NNX11AH20G).

\section{References}

Abbott B.W., Larouche J.R., Jones J.B. Jr., Bowden W.B. \& Balser A.W. 2014. Elevated dissolved organic carbon biodegradability from thawing and collapsing permafrost. Journal of Geophysical Research-Biogeosciences 119, 2049-2063.

Ågren A., Berggren M., Laudon H. \& Jansson M. 2008. Terrestrial export of highly bioavailable carbon from small boreal catchments in spring floods. Freshwater Biology 53, 964-972.

Algesten G., Sobek S., Bergström A.K. \& Jonsson A. 2005. Contribution of sediment respiration to summer $\mathrm{CO}_{2}$ emission from low productive boreal and Subarctic lakes. Microbial Ecology 50, 529-535.

Battin T.J., Kaplan L.A., Findlay S., Hopkinson C.S., Marti E., Packman A.I., Newbold J.D. \& Sabater F. 2008. Biophysical controls on organic carbon fluxes in fluvial networks. Nature Geoscience 1, 95-100.

Brown J., Ferrians O.J. Jr, Heginbottom J.A. \& Melnikov E. S. 1998 (revised 2001). Circum-Arctic map of permafrost and ground ice conditions. Boulder, CO: National Snow and Ice Data Center/World Data Center for Glaciology.

Cleveland C. \& Liptzin D. 2007. C:N:P stoichiometry in soil: is there a "Redfield ratio" for the microbial biomass? Biogeochemistry 85, 235-252.

Cole J.J., Prairie Y.T., Caraco N.F., McDowell W.H., Tranvik L.J., Striegl R.G., Duarte C.M., Kortelainen P., Downing J. A., Middelburg J.J. \& Melack J. 2007. Plumbing the global carbon cycle: integrating inland waters into the terrestrial carbon budget. Ecosystems 10, 172-185.

Cory R.M., Crump B.C. \& Dobkowski J.A. 2013. Surface exposure to sunlight stimulates $\mathrm{CO}_{2}$ release from permafrost soil carbon in the Arctic. Proceedings of the National Academy of Sciences of the United States of America 110, 3429-3434.

Cory R.M., Ward C.P., Crump B.C. \& Kling G.W. 2014. Sunlight controls water column processing of carbon in arctic fresh waters. Science 345, 925-928.

Davydov S.P., Fyodorov-Davydov D.G., Neff J.C., Shiklomanov N.I. \& Davydova A.I. 2008. Changes in active-layer thickness and seasonal fluxes of dissolved organic carbon as a possible baseline for permafrost monitoring. In Kane D.L. \& Hinkel K.M. (eds.): Ninth international conference on permafrost. Vol. 1. Pp. 333337. Fairbanks: Institute of Northern Engineering, University of Alaska Fairbanks.

Drake T.W., Wickland K.P., Spencer R.G.M., McKnight D. M. \& Striegl R.G. 2015. Ancient low-molecular-weight organic acids in permafrost fuel rapid carbon dioxide production upon thaw. Proceedings of the National Academy of Sciences 112, 13946-13951.

Dutta K., Schuur E.A.G., Neff J.C. \& Zimov S.A. 2006. Potential carbon release from permafrost soils of northeastern Siberia. Global Change Biology 12, 23362351.

Ellerbrock R.H., Höhn A. \& Gerke H.H. 1999. Characterization of soil organic matter from a sandy soil in relation to management practice using FTIR spectroscopy. Plant and Soil 213, 55-61.

Fenner N. \& Freeman C. 2011. Drought-induced carbon loss in peatlands. Nature Geoscience 4, 895-900.

Frauenfeld O.W., Zhang T. \& Barry R.G. 2004. Interdecadal changes in seasonal freeze and thaw depths in Russia. Journal of Geophysical Research-Atmospheres 109, D05101, doi: 10.1029/2003JD004245.

Frey K.E. \& McClelland J.W. 2009. Impacts of permafrost degradation on Arctic river biogeochemistry. Hydrological Processes 23, 169-182.

GOST. 2008. Grunty. Metody laboratoriogo opredelenija granulometričeskogo (zernovogo) i mikroagregatnogo sostava. GOST 12536-79. (Soils. Methods of laboratory granulometric [grain-size] and microaggregate distribution. GOST [State Standard] 12536-79.) Moscow: IPK Izdatelstvo Standartov.

Goulden M.L., Wofsy S.C. \& Harden J.W. 1998. Sensitivity of boreal forest carbon balance to soil thaw. Science 279, 214-217.

Granéli W., Bertilsson S. \& Philibert A. 2004. Phosphorus limitation of bacterial growth in High Arctic lakes and ponds. Aquatic Sciences 66, 430-439.

Greenberg A.E., Clesceri L.S., Eaton A.D. \& Franson M.A. H. (eds.) 1992. Standard methods for the examination of water and wastewater. 18th edn. Washington, DC: American Public Health Association.

Griffin C.G., Frey K.E. \& Rogan J. 2011. Spatial and interannual variability of dissolved organic matter in the Kolyma River, East Siberia, observed using satellite imagery. Journal of Geophysical Research-Biogeosciences 116, G03018, doi: 10.1029/2010JG001634.

He Z., Honeycutt C.W. \& Zhang H. 2011. Elemental and fourier transform-infrared spectroscopic analysis of water- and pyrophosphate-extracted soil organic matter. Soil Science 176, 183-189.

Hinkel K.M. \& Nelson F.E. 2003. Spatial and temporal patterns of active layer thickness at Circumpolar Active Layer Monitoring (CALM) sites in northern Alaska, 1995-2000. Journal of Geophysical ResearchAtmospheres 108, 183-189.

Hobbie J.E. \& Laybourn-Parry J. 2008. Heterotrophic microbial processes in polar lakes. In Vincent W.F. \& Laybourn-Parry J. (eds.): Polar lakes and rivers. Pp. 197212. Oxford: Oxford University Press.

Holmes R.M. \& McClelland J.W. 2008. Lability of DOC transported by Alaskan rivers to the Arctic Ocean. Geophysical Research Letters 35, L03402, doi: 10.1029/2007GL032837.

Holmes R.M., McClelland J.W., Peterson B.J., Tank S.E., Bulygina E., Eglinton T.I., Gordeev V.V., Gurtovaya 
T.Y., Raymond P.A., Repeta D.J., Staples R., Striegl R.G., Zhulidov A.V. \& Zimov S.A. 2012. Seasonal and annual fluxes of nutrients and organic matter from large rivers to the Arctic ocean and surrounding seas. Estuaries and Coasts 35, 369-382.

Hugelius G., Strauss J., Zubrzycki S., Harden J.W., Schuur E.A.G., Ping C.-L., Schirrmeister L., Grosse G., Michaelson G.J., Koven C.D., O’Donnell J.A., Elberling B., Mishra U., Camill P., Yu Z., Palmtag J. \& Kuhry P. 2014. Estimated stocks of circumpolar permafrost carbon with quantified uncertainty ranges and identified data gaps. Biogeosciences 11, 6573-6593.

Kalbitz K., Schmerwitz J., Schwesig D. \& Matzner E. 2003. Biodegradation of soil-derived dissolved organic matter as related to its properties. Geoderma 113, 273-291.

Kanevskiy M., Shur Y., Fortier D., Jorgenson M.T. \& Stephani E. 2011. Cryostratigraphy of Late Pleistocene syngenetic permafrost (yedoma) in northern Alaska, Itkillik River exposure. Quaternary Research 75, 584596.

Knoblauch C., Beer C., Sosnin A., Wagner D. \& Pfeiffer E.M. 2013. Predicting long-term carbon mineralization and trace gas production from thawing permafrost of northeast Siberia. Global Change Biology 19, 11601172.

Lapierre J.-F., Guillemette F., Berggren M. \& Del Giorgio P. A. 2013. Increases in terrestrially derived carbon stimulate organic carbon processing and $\mathrm{CO}_{2}$ emissions in boreal aquatic ecosystems. Nature Communications 4, article no. 2972, doi: 10.1038/ncomms3972.

Larouche J.R., Abbott B.W. \& Bowden W.B. 2015. The role of watershed characteristics, permafrost thaw, and wildfire on dissolved organic carbon biodegradability and water chemistry in Arctic headwater strams. Biogeosciences 12, 4221-4233.

Lee H., Schuur E.A.G., Inglett K.S., Lavoie M. \& Chanton J. P. 2012. The rate of permafrost carbon release under aerobic and anaerobic conditions and its potential effects on climate. Global Change Biology 18, 515-527.

Mann P.J., Davydova A., Zimov N., Spencer R.G.M., Davydov S., Bulygina E., Zimov S. \& Holmes R.M. 2012. Controls on the composition and lability of dissolved organic matter in Siberia's Kolyma River basin. Journal of Geophysical Research -Biogeosciences 117, G01028, doi: 10.1029/2011JG001798.

Mann P.J., Sobczak W.V., LaRue M.M., Bulygina E., Davydova A., Vonk J.E., Schade J., Davydov S., Zimov N., Holmes R.M. \& Spencer R.G.M. 2014. Evidence for key enzymatic controls on metabolism of Arctic river organic matter. Global Change Biology 20, 1089-1100.

Matzner E. \& Borken W. 2008. Do freeze-thaw events enhance $\mathrm{C}$ and $\mathrm{N}$ losses from soils of different ecosystems? A review. European Journal of Soil Science 59, 274-284.

McDowell W.H. \& Wood T. 1984. Podzolization: soil processes control dissolved organic carbon concentrations in stream water. Soil Science 137, 23-32.

McGuire A.D., Macdonald R.W., Schuur E.A.G., Harden J. W., Kuhry P., Hayes D.J., Christensen T.R. \& Heimann M. 2010. The carbon budget of the northern cryosphere region. Current Opinion in Environmental Sustainability 2, 231-236.

Neff J.C. \& Asner G.P. 2001. Dissolved organic carbon in terrestrial ecosystems: synthesis and a model. Ecosystems 4, 29-48.

Neff J.C., Finlay J.C., Zimov S.A., Davydov S.P., Carrasco J. J., Schuur E.A.G. \& Davydova A.I. 2006. Seasonal changes in the age and structure of dissolved organic carbon in Siberian rivers and streams. Geophysical Research Letters 33, L23401, doi: 10.1029/2006GL028222.

Ohno T., He Z., Tazisong I.A. \& Senwo Z.N. 2009. Influence of tillage, cropping, and nitrogen source on the chemical characteristics of humic acid, fulvic acid, and water-soluble soil organic matter fractions of a longterm cropping system study. Soil Science 174, 652-660.

Pribyl D.W. 2010. A critical review of the conventional SOC to SOM conversion factor. Geoderma 156(3-4), 75-83.

Rigler F.H. 1966. Radiobiological analysis of inorganic phosphorus in lakewater. Verhandlungen der Internationalen Vereinigung für Theoretische und Angewandte Limnologie 16, 465-470.

Romanovskij N.N. 1993. Osnov'y kriogeneza litosfery. (Fundamentals of cryogenesis of the lithosphere.) Moscow: Moscow State University.

Romanovsky V.E., Smith S.L. \& Christiansen H.H. 2010. Permafrost thermal state in the polar Northern Hemisphere during the international polar year 2007-2009: a synthesis. Permafrost and Periglacial Processes 21, 106-116.

Salvadó J.A., Tesi T., Andersson A., Ingri J., Dudarev O. V., Semiletov I.P., \& Gustafsson Ö.. 2015. Organic carbon remobilized from thawing permafrost is resequestered by reactive iron on the eurasian arctic shelf. Geophysical Research Letters 42, 8122-8130. doi: 10.1029/2010GL042909

Schirrmeister L., Grosse G., Wetterich S., Overduin P.P., Strauss J., Schuur E.A.G. \& Hubberten H.-W. 2011. Fossil organic matter characteristics in permafrost deposits of the northeast Siberian Arctic. Journal of Geophysical Research-Biogeosciences 116, G00M02, doi:10.1029/2011JG001647.

Schirrmeister L., Kunitsky V., Grosse G., Wetterich S., Meyer H., Schwamborn G., Babiy O., Derevyagin A. \& Siegert C. 2011. Sedimentary characteristics and origin of the Late Pleistocene Ice Complex on north-east Siberian Arctic coastal lowlands and islands-a review. Quaternary International 241, 3-25.

Schuur E.A.G., Bockheim J., Canadell J.G., Euskirchen E., Field C.B., Goryachkin S.V., Hagemann S., Kuhry P., Lafleur P.M., Lee H., Mazhitova G., Nelson F.E., Rinke A., Romanovsky V.E., Shiklomanov N., Tarnocai C., Venevsky S., Vogel J.G. \& Zimov S.A. 2008. Vulnerability of permafrost carbon to climate change: implications for the global carbon cycle. Bioscience 58, 701-714.

Schuur E.A.G., McGuire A.D., Schädel C., Grosse G., Harden J.W., Hayes D.J., Hugelius G., Koven C.D., Kuhry P., Lawrence D.M., Natali S.M., Olefeldt D., Romanovsky V.E., Schaefer K., Turetsky M.R., Treat C. C. \& Vonk J.E. 2015. Climate change and the permafrost carbon feedback. Nature 520, 171-179.

Sher A.V., Kaplina T.N., Giterman R.E., Lozhkin A., Archangelov A.A., Kiselyov S.V., Kouznetsov Y.V., Virina E.I. \& Zazhigin V.S. 1979. Late Cenozoic of the Kolyma Lowland: XIV Pacific Science Congress. Tour guide XI, Khabarovsk, August 1979. Moscow: Publications of the Academy of Science of the USSR.

Solov'ev P.A. 1959. Kriolitozona severnoj casti LenoAmginskogo meždurecija. (Permafrost zone of the northern part of the Lena-Amga interfluve.) Moscow: Publications of the Academy of Science of the USSR.

Spencer R.G.M., Mann P.J., Dittmar T., Eglinton T.I., McIntyre C., Holmes R.M., Zimov N. \& Stubbins A. 
2015. Detecting the signature of permafrost thaw in Arctic rivers. Geophysical Research Letters 42, 2830-2835.

Stocker T.F., Qin D., Plattner G.-K., Tignor M., Allen S.K., Boschung J., Nauels A., Xia Y., Bex V. \& Midgley P.M. (eds.) 2013. Climate change 2013. The physical science basis. Contribution of Working Group I to the fifth assessment report of the Intergovernmental Panel on Climate Change. Cambridge: Cambridge University Press.

Strauss J., Schirrmeister L., Grosse G., Wetterich S., Ulrich M., Herzschuh U. \& Hubberten H.-W. 2013. The deep permafrost carbon pool of the yedoma region in Siberia and Alaska. Geophysical Research Letters 40, 6165-6170.

Striegl R.G., Aiken G.R., Dornblaser M.M., Raymond P.A. \& Wickland K.P. 2005. A decrease in discharge-normalized DOC export by the Yukon River during summer through autumn. Geophysical Research Letters 32, L21413, doi: 10.1029/2005GL024413.

Tao S. \& Lin B. 2000. Water soluble organic carbon and its measurement in soil and sediment. Water Research 34, 1751-1755.

Tarnocai C., Canadell J.G., Schuur E.A.G., Kuhry P., Mazhitova G. \& Zimov S. 2009. Soil organic carbon pools in the northern circumpolar permafrost region. Global Biogeochemical Cycles 23, GB2023, doi: 10.1029/ 2008 GB003327.

Taylor B.W., Keep C.F., Hall R.O., Koch B.J., \& Tronstad L. M. 2007. Improving the fluorometric ammonium method: matrix effects, background fluorescence, and standard additions. Journal Of The Nprth American Bentholical Society 26, 167-177.

Vonk J.E., Mann P.J., Davydov S., Davydova A., Spencer R.G. M., Schade J., Sobczak W.V., Zimov N., Zimov S., Bulygina E., Eglinton T.I. \& Holmes R.M. 2013. High biolability of ancient permafrost carbon upon thaw. Geophysical Research Letters 40, 2689-2693, doi: 10.1002/grl.50348.

Vtyurin B.I. 1975. Podzemnye l'dy SSSR. (Ground ice of the USSR.) Moscow: Nauka.
Walter Anthony K.M., Zimov S.A., Grosse G., Jones M.C. Anthony P.M., Chapin F.S. III, Finlay J.C., Mack M.C., Davydov S., Frenzel P. \& Frolking S. 2014. A shift of thermokarst lakes from carbon sources to sinks during the Holocene epoch. Nature 511, 452-456.

Walter K.M., Edwards M.E., Grosse G., Zimov S.A. \& Chapin F.S. 2007. Thermokarst lakes as a source of atmospheric $\mathrm{CH} 4$ during the last deglaciation. Science 318, 633-636.

Wang J., Song C., Hou A. \& Wang L. 2014. $\mathrm{CO}_{2}$ emissions from soils of different depths of a permafrost peatland, northeast China: response to simulated freezing-thawing cycles. Journal of Plant Nutrition and Soil Sciences 177, 524-531.

Wickland K.P., Neff J.C. \& Aiken G.R. 2007. Dissolved organic carbon in Alaskan boreal forest: sources, chemical characteristics, and biodegradability. Ecosystems 10, 1323-1340.

Zhang T., Frauenfeld O.W. \& Serreze M.C. 2005. Spatial and temporal variability in active layer thickness over the Russian Arctic drainage basin. Journal of Geophysical Research-Atmospheres 110, D16101, doi: 10.1029/ 2004JD005642.

Zimov S.A., Davydov S.P., Zimova G.M., Davydova A.I., Schuur E.A.G., Dutta K. \& Chapin F.S.III 2006. Permafrost carbon: stock and decomposability of a globally significant carbon pool. Geophysical Research Letters 33, L20502, doi: 10.1029/2006GL027484.

Zimov S.A., Schuur E.A.G. \& Chapin F.S. III, 2006. Permafrost and the global carbon budget. Science 312, 1612-1613.

Zimov S.A., Semiletov I.P., Daviodov S.P., Voropaev Y.V., Prosyannikov S.F., Wong C.S. \& Chan Y.-H. 1993. Wintertime $\mathrm{CO}_{2}$ emission from soils of northeastern Siberia. Arctic 46, 197-204.

Zimov S.A., Voropaev Y.V., Semiletov I.P. \& Davidov S.P. 1997. North Siberian lakes: a methane source fueled by Pleistocene carbon. Science 277, 800-802. 